\title{
Long-Term Outcomes of Chest Wall Resection in Non- Small Cell Lung Cancer in Geriatric Patients
}

\section{Geriatrik Hastalarda Küçük Hücreli Olmayan Akciğer Kanserinde Göğüs Duvarı Rezeksiyonunun Uzun Dönem Sonuçları}

\author{
๑ Celal Buğra Sezen, ๑ Süleyman Anıl Akboğa* , ๑ Abdullah İrfan Tastepe** , Sedat Demircan** \\ istanbul Yedikule Chest Diseases and Thoracic Surgery Training and Research Hospital, Clinic of Thoracic Surgery, Istanbul, Turkey \\ *Bingöl State Hospital, Clinic of Thoracic Surgery, Bingöl, Turkey \\ **Gazi University Faculty of Medicine, Department of Thoracic Surgery, Ankara, Turkey
}

Abstract

Aim: Lung cancer has become a global health problem today. Both patients and physicians prefer oncologic treatment approaches rather than surgery in T3 and T4 lung cancers in the geriatric age group. The objective of this study was to assess the long-term survival outcomes of patients aged 70 years and older, who underwent chest wall resection due to non-small cell lung cancer, and the prognostic factors affecting morbidity.

Methods: Eighteen patients, who underwent chest wall resection due to non-small cell lung cancer, were assessed retrospectively.

Results: A total of 18 patients ( 16 male and 2 female) with a mean age of $74.28 \pm 3.81$ years were included in the study. The most common surgery was right upper lobectomy $(55.6 \%, \mathrm{n}=10)$. Complications were detected in nine patients (50\%). The most common complication was arrhythmia. Mortality was detected in four patients (22\%). The mean two-year and five-year survival rates were $77.9 \%$ and $41.4 \%$, respectively. Lymph node status, adjuvant treatment and tumor stage were prognostic factors affecting survival $(\mathrm{p}=0.001)$.

Conclusion: Age should not be the only criterion for surgery. Appropriately selected patients should be offered anatomical resection. Long-term survival can be achieved in these patients.

Keywords: Thoracic wall resection, geriatric thoracic surgery, nonsmall cell lung cancer, advanced stage tumors
Amaç: Akciğer kanseri günümüzde global bir sorun haline gelmiştir. Geriatrik yaş grubundaki T3 ve T4 akciğer kanserlerinde hastalar ve doktorlar cerrahiden ziyade onkolojik tedavi yaklaşımlarını tercih etmektedirler. Bizim bu çalışmadaki amacımız 70 yaş ve üzerinde küçük hücreli dışı akciğer kanseri nedeniyle toraks duvar rezeksiyonu yapılan hastaların uzun dönem sağkalım sonuçlarını ve morbiditeye etki eden prognostik faktörleri değerlendirmektir.

Yöntemler: Küçük hücreli dışı akciğer kanseri nedeniyle toraks duvar rezeksiyonu operasyonu yapılan 18 hasta retrospektif olarak değerlendirildi.

Bulgular: On altı erkek, iki kadın hastanın yer aldığı çalışmada hastaların ortalama yaşı $74,28 \pm 3,81$ yl idi. En sık yapılan operasyon sağ üst lobektomi idi (\%55,6, n=10). Dokuz hastada (\%50) komplikasyon saptandı. En sık saptanan komplikasyon aritmi şikayetiydi. Dört hastada (\%22) mortalite saptandı. Ortalama iki yıllık sağkalım oranı \%77,9; beş ylllık sağkalım oranı \%41,4 idi. Lenf nodu durumu, adjuvan tedavi alması ve tümörün evresi sağkalımı etkileyen prognostik faktörlerdir $(p=0,001)$.

Sonuç: Yaş tek başına operasyon için kriter olmamalıdır. Özellikle seçilmiş hastalarda tedavi amacıyla anatomik rezeksiyon önerilmelidir. Bu hastalarda uzun dönem sağkalım izlenebilmektedir.

Anahtar Sözcükler: Torasik duvar rezeksiyonu, geriatrik torasik cerrahi, küçük hücreli dışı akciğer kanseri, ileri evre tümörler

\section{Introduction}

The number of people aged 70 years and over is constantly growing in the western countries. The elderly population of Turkey constituted $7.7 \%$ of the nation's total in 2013. This ratio is expected to increase up to $12.2 \%$ in 2020 (1). With aging, the incidence of cancer increases. Lung cancer has become a global health problem.
Address for Correspondence/Yazışma Adresi: Celal Buğra Sezen Istanbul Yedikule Chest Diseases and Thoracic Surgery Training and Research Hospital, Clinic of Thoracic Surgery, istanbul, Turkey

Phone: +90 2124090202 E-mail: info@bugrasezen.com ORCID ID: orcid.org/0000-0002-2461-2031 Received/Geliş Tarihi: 11 October 2017 Accepted/Kabul Tarihi: 11 April 2018
${ }^{\circ}$ Copyright 2018 by The Medical Bulletin of University of Health Sciences Haseki Training and Research Hospital
The Medical Bulletin of Haseki published by Galenos Yayınevi.

${ }^{\circledR}$ Telif Hakkı 2018 Sağlık Bilimleri Üniversitesi Haseki Eğitim ve Araştırma Hastanesi Haseki Tıp Bülteni, Galenos Yayınevi tarafından basıımıştır. 
Worldwide, approximately 1.2 million people are newly diagnosed with lung cancer annually. Accordingly, more than 1 million die of the disease every year. In their study, made between 1993 and 1996, the Southwest Oncology Group found that $25 \%$ of the population was in the geriatric age group and 39\% of the geriatric population had lung cancer (2). Both patients and doctors prefer oncologic treatment approaches rather than surgery in T3 and T4 lung cancers in the geriatric age group. The most important reason for this is that comorbid diseases and post-surgery complications are seen more often in this population.

In this study, we assessed the long-term survival outcomes in patients 70 years of age and older who underwent thoracic wall resection due to non-small cell lung cancer (NSCLC) and the prognostic factors affecting morbidity.

\section{Methods}

Ethics committee approval was obtained for the study from the University of Health Sciences, Keçiören Training and Research Hospital (version number: 497). The consent of the patients included in the study was taken by the authors.

Data of patients, who underwent wall resection due to NSCLC in the department of thoracic surgery in Gazi University Faculty of Medicine between January 2007 and December 2014, were reviewed retrospectively from the data-set prepared prospectively. A thousand and forty-eight patients were operated on for NSCLC in the above-mentioned period. From these patients, 19 patients in the geriatric age group, who underwent an RO chest wall resection, were assessed. One patient, whose data could not be obtained, was excluded from the study. The remaining 18 patients were retrospectively evaluated.

Detailed anamneses, physical examinations, electrocardiography, respiratory function tests and standard laboratory tests of the patients were reviewed. All patients had been assessed with lung X-ray, computed tomography (CT) and fiberoptic bronchoscopy before surgery. Magnetic resonance imaging (MRI) had been required for patients who were suspected of having paravertebral sulcus or vertebral or vascular invasion. Positron emission tomography (PET)/CT and cranial MRI had been performed in all patients for clinical staging and screening for distant metastasis.

$\mathrm{PET} / \mathrm{CT}$, endobronchial ultrasonography and mediastinoscopy had been used to assess the lymph node status. All patients were evaluated with mediastinoscopy before resection.

Three patients had been administered neoadjuvant therapy. All patients had undergone lobectomy and pneumonectomy together with en bloc chest wall resection. Postoperative pathological staging was done according to the $8^{\text {th }}$ edition of the tumor node metastasis classification for lung cancer (3). Patients whose tumor diameter was $7 \mathrm{~cm}$ and above were accepted as having T3 according to the International Association for the Study of Lung Cancer (IASLC) 7th lung cancer staging. In our study, we accepted this group as T4, according to the IASLC $8^{\text {th }}$ Edition (3).

The postoperative comorbid diseases were divided into three groups: endocrine disorders (diabetes and goiter), cardiac problems (hypertension, heart failure and coronary artery disease), and pulmonary problems (asthma and chronic obstructive pulmonary disease).

Major complications were assessed in the study. The complications occurring from postoperative day one to day 30 were included in the study. The complications were postoperative arrhythmia, renal failure, atelectasis, pneumonia, empyema, and bronchopleural fistula.

The patients were followed up through physical examination and thoracic CT quarterly for two years, semiannually after two years, and annually after five years.

\section{Statistical Analysis}

Statistical analysis was done using the SPSS version 22.0 (SPSS Inc., Chicago, IL, USA). For descriptive statistics, a chi-square test was used to calculate frequency values, Student's t-test was used in independent groups to compare means, and the Mann-Whitney $U$ test was used to compare medians. Patient survey analyses were calculated using the Kaplan-Meier method. Since the number of patients aged 80 and over was too small among the age groups for achieving statistical significance, these patients were included in the group of patients aged 75 and over. A p value of 0.05 was considered statistically significant.

\section{Results}

The mean age of the patients was $74.28 \pm 3.81$ (minimum: 70, maximum: 84 ) years; $88.9 \%$ of them were male $(n=16)$ and $11.2 \%$ were female $(n=2)$. The mean

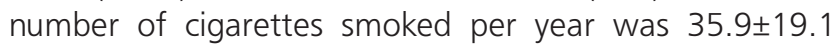
(minimum: 0, maximum: 70) packs. The rate at which the patients quit smoking before the operation was $88.9 \%$ $(n=16)$. The preoperative diagnosis rate was $66.7 \%(n=6)$. The distribution of demographic characteristics by the groups is shown in Table 1.

Mostly, right chest wall resections were done in the geriatric age group $(61.1 \%, \mathrm{n}=11)$. The most frequent resection type was upper right lobectomy with 55.6\% $(n=10)$ (Table 2). Of the patients who underwent chest wall resection, $27.8 \%(n=5)$ were operated due to Pancoast tumor. Four of the Pancoast tumors were right-sided, and one was left-sided. 


\begin{tabular}{|l|l|}
\hline \multicolumn{2}{|l|}{ Table 1. Distribution of demographic characteristics } \\
\hline Age (year), mean \pm SD & $74.28 \pm 3.81$ \\
\hline Gender, $\mathbf{n}(\%)$ & $16(88.9)$ \\
\hline Male & $2(11.1)$ \\
\hline Female & $35.9 \pm 19.1$ \\
\hline $\begin{array}{l}\text { Smoking habit (packet/year), } \\
\text { mean } \pm \text { SD }\end{array}$ & $14(77.8)$ \\
\hline Preoperative comorbidities, $\mathbf{n}(\%)$ & $8(44.4)$ \\
\hline Cardiac & $6(33.3)$ \\
\hline Pulmonary & \multicolumn{2}{|l|}{} \\
\hline Endocrinologic & $9(50)$ \\
\hline ASA, $\mathbf{n}$ (\%) & $6(33.3)$ \\
\hline 2 & $3(16.7)$ \\
\hline 3 & Standard deviation \\
\hline 4 &
\end{tabular}

\begin{tabular}{|l|l|}
\hline \multicolumn{2}{|l|}{ Table 2. Operations involved in thoracic wall resections } \\
\hline Resection types, $\mathbf{n}(\%)$ & $10(55.6)$ \\
\hline Upper right lobectomy & $1(5.6)$ \\
\hline Lower right lobectomy & $3(16.7)$ \\
\hline Upper left lobectomy & $1(5.6)$ \\
\hline Lower left lobectomy & $3(16.7)$ \\
\hline Left pneumonectomy &
\end{tabular}

\begin{tabular}{|l|l|}
\hline \multicolumn{2}{|l|}{ Table 3. Clinical and pathological data of patients } \\
\hline Histopathology, $\mathbf{n}(\%)$ & $6(33.3)$ \\
\hline Adenocarcinoma & $10(55.6)$ \\
\hline Squamous cell carcinoma & $2(11.1)$ \\
\hline Other lung carcinomas & $10.56 \pm 8.02$ \\
\hline Hospitalization time (days), mean \pm SD & $6.06 \pm 4.09$ \\
\hline Drainage time (days), mean \pm SD & \\
\hline SD: Standard deviation & \\
\hline
\end{tabular}

A review of postoperative pathologies showed that squamous cell carcinoma was the most common with $55.6 \%(n=0)$. The mean length of hospital stay was 10.56 \pm 8.02 (minimum: 4 - maximum: 30) days, and the mean drainage time was $6.06 \pm 4.09$ (minimum: 2, maximum: 18) days (Table 3). The mean tumor diameter was $5.27 \pm 2.25$ (minimum: 2 - maximum: 11.5 ) cm. When their pathological stages were assessed in line with the IASLC $8^{\text {th }}$ Edition of Staging, stage $3 \mathrm{~A}$ was the most common in both groups. Histopathological features of the patients are shown in Table 4. Major complications were found in $50 \%(n=9)$ of patients. The most common complication was arrhythmia in $50 \%$ of cases. The features of complications are shown in Table 5.

\begin{tabular}{|l|l|}
\hline \multicolumn{2}{|l|}{ Table 4. Histopathological characteristics } \\
\hline Tumor diameter (cm), mean \pm SD & $5.27 \pm 2.25$ \\
\hline N status, $\mathbf{n}(\%)$ & $9(50)$ \\
\hline N0 & $8(44.4)$ \\
\hline N1 & $1(5.6)$ \\
\hline N2 & $8(44.4)$ \\
\hline $8^{\text {th }}$ edition of staging, $\mathbf{n}(\%)$ & $9(50)$ \\
\hline 2b & $1(5.6)$ \\
\hline 3a & $23.06 \pm 11.17$ \\
\hline 3b & \\
\hline $\begin{array}{l}\text { Number of removed lymph } \\
\text { nodes, mean } \pm \text { SD }\end{array}$ & \\
\hline SD: Standard deviation &
\end{tabular}

\begin{tabular}{|l|l|}
\hline \multicolumn{2}{|l|}{ Table 5. Postoperative major complications } \\
\hline Variables, $\mathbf{n}(\%)$ & $5(27.8)$ \\
\hline Atelectasia & $9(50)$ \\
\hline Arrhythmia & $2(11.1)$ \\
\hline Bronchopleural fistula & $4(22.2)$ \\
\hline Acute kidney failure & $5(27.8)$ \\
\hline Pneumonia & $2(11.1)$ \\
\hline Emphysema &
\end{tabular}

Mortality occurred in four patients (22\%) in the first 30 days. All the patients who died were those who underwent lobectomy. There was no mortality in patients who underwent pneumonectomy. The rate of mortality was significantly higher in patients with higher American Society of Anesthesiologists scores $(p=0.01)$. While preoperative cardiac and pulmonary comorbidities were not found to be correlated with mortality, endocrinologic comorbidities were associated with a higher mortality rate $(p=0.04)$.

The mean survival rate was $47.5 \pm 7.5$ months in patients who underwent chest wall resection; the twoyear survival rate was $77.9 \%$ and the five-year survival rate was $41.4 \%$ (Figure). A comparison of the factors affecting survival is shown in Table 6 .

\section{Discussion}

The geriatric patient population is rapidly growing today due to advanced treatment methods and improved living conditions. The prevalence of lung cancer has increased up to $14 \%$, particularly in those aged 80 years and over (4). In addition, lung cancers are more common in male gender in geriatric patients (4). In our study, $88.9 \%$ of patients who underwent chest wall resection were male.

Cardiopulmonary complications are among the major causes of mortality and morbidity in the geriatric age group. Pulmonary complications are seen in $20-50 \%$ 


\begin{tabular}{|c|c|c|c|c|c|}
\hline & \begin{tabular}{|l} 
Mean \\
survival \\
(Months), \\
mean \pm \\
SD
\end{tabular} & $\begin{array}{l}95 \% \\
\text { Confidence } \\
\text { interval }\end{array}$ & $\begin{array}{l}\text { Two- } \\
\text { year } \\
\text { survival } \\
(\%)\end{array}$ & $\begin{array}{l}\text { Five- } \\
\text { year } \\
\text { survival } \\
\text { (\%) }\end{array}$ & $p$ \\
\hline \multicolumn{6}{|l|}{ Age group } \\
\hline $\begin{array}{l}\text { Age } 70-74 \\
(n=10)\end{array}$ & $48.8 \pm 8.4$ & $32.1-65.4$ & 78.8 & 39.4 & \multirow[t]{2}{*}{0.90} \\
\hline Age $>75(n=4)$ & $35.2 \pm 10.0$ & $15.4-55.0$ & 50 & 0 & \\
\hline \multicolumn{6}{|l|}{ Resection type } \\
\hline $\begin{array}{l}\text { Lobectomy } \\
(n=11)\end{array}$ & $48.1 \pm 8.4$ & $31.6-64.6$ & 81.8 & 43.6 & \multirow{2}{*}{0.59} \\
\hline $\begin{array}{l}\text { Pneumonectomy } \\
(n=3)\end{array}$ & $25.5 \pm 0.3$ & $24.8-26.1$ & 50 & NS & \\
\hline $\begin{array}{l}\text { Neoadjuvant } \\
\text { treatment }(n=3)\end{array}$ & $16 \pm 7.6$ & $1.0-30.9$ & 33.3 & 0 & \multirow{2}{*}{0.03} \\
\hline $\begin{array}{l}\text { Adjuvant } \\
\text { treatment }(n=11)\end{array}$ & $56.6 \pm 7.5$ & $7.5-41.8$ & 90 & 27 & \\
\hline \multicolumn{6}{|l|}{ Histopathology } \\
\hline $\begin{array}{l}\text { Adenocarcinoma } \\
(\mathrm{n}=5)\end{array}$ & $37.5 \pm 5.5$ & $27.3-47.6$ & 100 & 25 & \multirow[b]{2}{*}{0.22} \\
\hline $\begin{array}{l}\text { Squamous cell } \\
\text { carcinoma }(n=7)\end{array}$ & $60 \pm 10.5$ & 39.9-80.1 & 85 & 64.3 & \\
\hline \multicolumn{6}{|l|}{$\mathrm{N}$ status } \\
\hline NO $(n=6)$ & $43.6 \pm 10.9$ & $22.1-65.1$ & 66.7 & 33.3 & \multirow{3}{*}{0.001} \\
\hline N1 $(n=7)$ & $48 \pm 5.0$ & $38.1-57.8$ & 100 & 60 & \\
\hline$N 2(n=1)$ & 6 & $6-6$ & 0 & 0 & \\
\hline \multicolumn{6}{|l|}{ Stage } \\
\hline $2 B(n=5)$ & $50.2 \pm 10.8$ & $29.0-71.3$ & 100 & 40 & \multirow{3}{*}{0.001} \\
\hline $3 A(n=8)$ & $43.3 \pm 6.1$ & $31.2-55.4$ & 87.5 & 52.5 & \\
\hline $3 B(n=1)$ & 6 & $6-6$ & 0 & 0 & \\
\hline
\end{tabular}
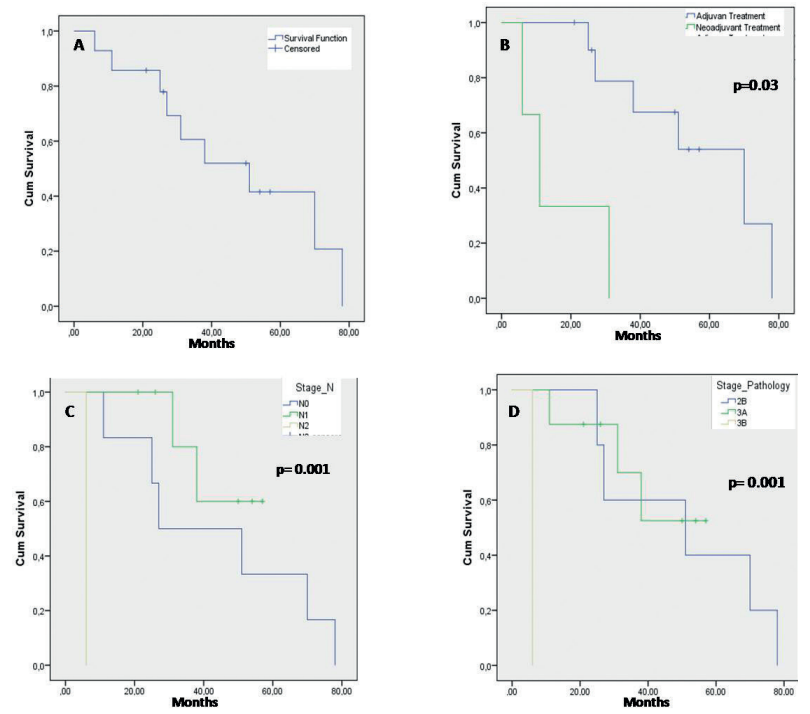

Figure. Kaplan-Meier graph of survivals

A. Median survival, B. Adjuvant and neoadjuvant treatment survival, C. N stage survival, D. $8^{\text {th }}$ lung cancer pathological stage of patients. These complications occur mostly due to preoperative pulmonary function disorders or long-term smoking. Postoperative respiratory failure or complications associated with secretion retentions are seen in patients with a restricted respiratory function reserve in the preoperative period. Lee et al. (5) have reported that the rate of major morbidity was $13 \%$ in geriatric patients. They have stressed that from these major morbidities, pneumonia, in particular, had a negative impact on the postoperative clinics of patients. Pneumonia occurred in five patients $(27.8 \%)$ in our study. After pneumonia, four patients needed a mechanical ventilator and their prognosis was extremely poor. Arrhythmia was seen more frequently in patients aged 75 years and over, and this was statistically significant $(p=0.01)$.

While lung cancer is seen more in the form of adenocarcinoma in younger people, squamous cell carcinoma is more common in patients older than 70 years. In their study of 212,709 geriatric patients with lung cancer, Owonikoko et al. (4) found that squamous cell carcinoma was the leading cancer type, involving 23\% of the patients. In our study, we found that squamous cell carcinoma was the most common type with $55.6 \%$ of patients aged 70 years and over.

Japanese literature on mortality revealed no postoperative mortality in the two series conducted with those aged 80 and over $(6,7)$. However, since the number of patients was 35, and 18 in these publications, it is difficult to make comparison between them and other papers (8). In the series where mortality was high, the incidence of stage 3 was found to be higher. Mizushima et al. (9) found in their study made in 1997 that the mortality rate was $22 \%$ after pneumonectomy in patients aged 70 and over. In our study, there was no mortality after pneumonectomy. We think that this was due to the small number of patients.

The data in the literature regarding the treatment of locally advanced NSCLC are quite inadequate. In superior sulcus tumors, the mortality rate was found to be $0-6.4 \%$ in patients under 70 years of age (10-15). The mortality rate of lung resections in the geriatric age group is $0-20 \%(11)$. In the study of Sağıroğlu et al. (16), there was no statistically significant difference in 30-day mortality between patients below and over 70 years of age $(p=0.97)$. The mortality rate in our study was $22 \%(n=4)$. Our mortality rate in the geriatric age group was found to be higher than in the literature. The reason is that our patients had a lot of comorbidities and our sample size was small. Differing results are ranging from $24 \%$ to $66 \%$ in the literature on five-year survival rates in geriatric patients $(11,17-20)$. In their series with 367 cases of stage 1 NSCLC, Okami et al. (17) found a five-year survival rate of $56.1 \%$. Brock et al. 
(21) found in their 20-year follow-up outcomes of stage one patients that they had a five-year survival rate of $34 \%$. The highest five-year survival rate in the studies made with geriatric patients was found in a study by Mun and Kohno (19). In 2008, they found a survival rate of $65.9 \%$. Some authors argued about the high rates of Kohno's survey, stating that the patients included in the study were quite selective, and smaller surgeries besides pneumonectomy were administered to the patients in the study (11). The major reasons for obtaining differing survival rates are the small number of patients and uncompleted follow-up periods. The five-year survival rate we found in our study was $41.4 \%$ in patients with T3-T4 lung cancers.

In our study, N2-positive group was found to be fewer than. other reviews. We think that the most important reason is that we performed mediastinoscopy in all patients before resection.

van Meerbeeck et al. (22) found a five-year survival rate of $33 \%$ after pneumonectomy. In our study, the two-year survival rate in patients who underwent a pneumonectomy was $50 \%$.

\section{Study Limitations}

We found fewer risk factors and higher mortality rates compared to that in the literature because the number of patients was small in our study. The retrospective design of the study may also have affected the results because today's advanced postoperative care and surgical techniques have changed the morbidity rates. Apart from these, five-year survival rates could not be established for some patients, as their follow-up periods were not long enough. The reason for high mortality rates in the study is that our patients had lots of comorbidities.

\section{Conclusion}

We can conclude that the postoperative outcomes of patients in the geriatric age group who undergo an operation are quite favorable in experienced centers. Our findings suggest that complication rates increase as patient age advances, however, we think that these patients should be offered anatomical surgical resection because long-term morbidity and mortality outcomes are favorable in experienced centers. Appropriately selected geriatric patients should be offered anatomic surgical resection for cure. These patients can anticipate long-term survival and should not be denied surgery on the basis of age alone.

\section{Authorship Contributions}

Surgical and Medical Practices: C.B.S., A.I.T., S.D., S.A.A. Concept: C.B.S., A.A. Design: C.B.S., A.A., A.I.T. Data Collection or Processing: C.B.S. Analysis or Interpretation: C.B.S., S.D. Literature Search: C.B.S., A.I.T. Writing: C.B.S., S.D.
Conflict of Interest: No conflict of interest was declared by the authors.

Financial Disclosure: The authors declared that this study received no financial support.

\section{References}

1. Kurumu TI. Yıllara, Yaş Grubu ve Cinsiyete Göre Nüfus, Genel Nüfus Sayımları - ADNKS [Internet]. 2013.

2. Hutchins LF, Unger JM, Crowley JJ, Coltman Jr CA, Albain KS. Underrepresentation of patients 65 years of age or older in cancer-treatment trials. N Engl J Med 1999;341:2061-7.

3. Goldstraw P, Chansky K, Crowley J, Rami-Porta R, Asamura $\mathrm{H}$, Eberhardt WEE, et al. The IASLC Lung Cancer Staging Project: proposals for revision of the TNM stage groupings in the forthcoming (eighth) edition of the TNM classification for lung cancer. J Thorac Oncol 2016;11:39-51.

4. Owonikoko TK, Ragin CC, Belani CP, Oton AB, Gooding WE, Taioli $E$, et al. Lung cancer in elderly patients: An analysis of the surveillance, epidemiology, and end results database. J Clin Oncol 2007;25:5570-7.

5. Lee PC, Levin MA, Flieder D. Surgical Resection for Lung Cancer in the Octogenarian. Chest 2004;126:733-8.

6. Hanagiri T, Muranaka H, Hashimoto M, Nagashima A, Yasumoto K. Results of surgical treatment of lung cancer in octogenarians. Lung Cancer 1999;23:129-33.

7. Aoki T, Yamato Y, Tsuchida M, Watanabe T, Hayashi J, Hirono T. Pulmonary complications after surgical treatment of lung cancer in octogenarians. Eur J cardio-thoracic Surg 2000; 18:662-5.

8. Dominguez-Ventura A, Allen MS, Cassivi SD, Nichols III FC, Deschamps C, Pairolero PC. Lung cancer in octogenarians: factors affecting morbidity and mortality after pulmonary resection. Ann Thorac Surg 2006;82:1175-9.

9. Mizushima MD Y, Noto MD H, Sugiyama MD S, Kusajima MD Y, Yamashita MD R, Kashii MD T, et al. Survival and prognosis after pneumonectomy for lung cancer in the elderly. Ann Thorac Surg 1997;64:193-8.

10. Demir A, Sayar A, Kocaturk Cl, et al. Surgical treatment of superior sulcus tumors: results and prognostic factors. Thorac Cardiovasc Surg 2009;57:96-101.

11. Guerra M, Neves P, Miranda J. Surgical treatment of nonsmall-cell lung cancer in octogenarians. Interact Cardiovasc Thorac Surg 2013;16:673-80.

12. Mansour Z, Kochetkova EA, Santelmo N, et al. Risk factors for early mortality and morbidity after pneumonectomy: a reappraisal. Ann Thorac Surg [Internet] 2009;88:1737-43.

13. Kutlu Ca, Ölçmen A, Sayar A, Metin M, Ölçmen M. Early Result of The Surgical Treatment of Superior Sulcus Tumours. Turkish J Thorac Cardiovasc Surg 2006:71-8.

14. Çıtak N, Metin M. Superior Sulkus Tümörlerinde (Pancoast) Güncel Yaklaşım. Güncel Göğüs Hast Serisi 2013;1:70-84.

15. Şahin E, Güngör A, Kaya A. Torasik Çıkış Tümörlerinde Cerrahi Tedavi 2000;50:24-8. 
16. Sağıroğlu G, Çopuroğlu E, Meydan B, et al. Pnömonektomi sonrasında erken morbidite ve mortalitenin risk faktörleri. Türk Göğüs Kalp Damar Cerrahisi Derg 2014;22:368-75.

17. Okami J, Higashiyama M, Asamura H, et al. Pulmonary resection in patients aged 80 years or over with clinical stage I non-small cell lung cancer: prognostic factors for overall survival and risk factors for postoperative complications. J Thorac Oncol 2009;4:1247-53.

18. Suemitsu R, Yamaguchi M, Takeo S, et al. Favorable surgical results for patients with nonsmall cell lung cancer over 80 years old: a multicenter survey. Ann Thorac Cardiovasc Surg 2008;14:154-60.
19. Mun M, Kohno T. Video-assisted thoracic surgery for clinical stage I lung cancer in octogenarians. Ann Thorac Surg 2008;85:406-11.

20. Dell'Amore A, Monteverde M, Martucci N, et al. Early and longterm results of pulmonary resection for non-small-cell lung cancer in patients over 75 years of age: a multi-institutional study. Interact Cardiovasc Thorac Surg 2013;16:250-6.

21. Brock MV, Kim MP, Hooker CM, et al. Pulmonary resection in octogenarians with stage I nonsmall cell lung cancer: a 22year experience. Ann Thorac Surg 2004;77:271-7.

22. van Meerbeeck JP, Damhuis RAM, Vos de Wael ML. High postoperative risk after pneumonectomy in elderly patients with right-sided lung cancer. Eur Respir J 2002;19:141-5. 